\title{
Effect of speech therapy and pharmacological treatment in prosody of parkinsonians
}

\author{
Efeito dos tratamentos fonoaudiológico e medicamentoso na prosódia de parkinsonianos \\ Luciana Lemos de Azevedo ${ }^{1}$, Irene Soares de Souza ${ }^{2}$. Patrícia Marques de Oliveira ${ }^{3}$. Francisco Cardoso ${ }^{4}$
}

\begin{abstract}
Objective: Parkinsonian patients usually present speech impairment. The aim of this study was to verify the influence of levodopa and of the adapted Lee Silverman Vocal Treatment ${ }^{\mathbb{R}}$ method on prosodic parameters employed by parkinsonian patients. Method: Ten patients with idiopathic Parkinson's disease using levodopa underwent recording of utterances produced in four stages: expressing attitudes of certainty and doubt and declarative and interrogative modalities. The sentences were recorded under the effect of levodopa (on), without the effect of levodopa (off); before and after speech therapy during the on and off periods. Results: The speech therapy and its association with drug treatment promoted the improvement of prosodic parameters: increase of fundamental frequency measures, reduction of measures of duration and greater intensity. Conclusion: The association of speech therapy to medication treatment is of great value in improving the communication of parkinsonian patients.
\end{abstract}

Keywords: Parkinson's disease, speech acoustics, levodopa, attitude, speech therapy.

RESUMO

Objetivo: Pacientes parkinsonianos habitualmente apresentam comprometimento na fala. 0 objetivo do presente estudo foi verificar a interferência da levodopa e do método Lee Silverman de Tratamento Vocal ${ }^{\circledR}$ adaptado nos parâmetros prosódicos empregados por parkinsonianos. Método: Dez indivíduos com doença de Parkinson idiopática em uso de levodopa foram submetidos à gravação de enunciados produzidos em quatro momentos: expressando as atitudes de certeza e dúvida e as modalidades declarativa e interrogativa. Os enunciados foram gravados sob o efeito da levodopa (on), fora do efeito da mesma (off); antes e após o tratamento fonoaudiológico, nos períodos on e off. Resultados: O tratamento fonoaudiológico e a associação dos tratamentos fonoaudiológico e medicamentoso promoveram a melhora dos parâmetros prosódicos: aumento das medidas de frequência fundamental, redução das medidas de duração e maior intensidade. Conclusão: A associação do tratamento fonoaudiológico ao medicamentoso é de grande valia na melhora da comunicação dos parkinsonianos.

Palavras-chave: doença de Parkinson, acústica da fala, levodopa, atitude, fonoterapia.

Parkinson's disease (PD) is a degenerative disorder of the central nervous system that affects mainly the motor system $^{1}$. The oral communication disorders are very common in these individuals and are characterized by monotonous frequency, low intensity variation ${ }^{2}$, low intensity feeling ${ }^{3,4}$, hoarsely-rough-soprous voice, vocal tremor, prosodic insufficiency $^{1,5}$, articulatory imprecision ${ }^{1,4,5,6,7}$, disfluency ${ }^{5}$ and changes in speech rate ${ }^{4,7}$. These changes can occur in the early stages of the disease and increase the intensity and frequency of occurrence throughout the duration and course of the disease ${ }^{8,9}$. The difficulty in communication can lead to social isolation ${ }^{3}$.

Eventually, all patients with PD will be treated with the most effective drug, the levodopa, which is converted to dopamine $^{10}$. However, some studies ${ }^{2,11}$ found that the effect of this drug on prosodic aspects of parkinsonian speech is modest, as few prosodic variables were modified after levodopa's use. This indicates that other therapeutic measures such as speech therapy may play a role in the treatment of speech disorders in PD.

\footnotetext{
1Departamento de Fonoaudiologia, Pontifícia Universidade Católica de Minas Gerais, Belo Horizonte, MG, Brazil;

${ }^{2}$ Fala - Clínica e Consultoria em Saúde, Belo Horizonte, MG, Brazil;

${ }^{3}$ Universidade Federal de Minas Gerais, Belo Horizonte, MG, Brazil;

${ }^{4}$ Departamento de Clínica Médica, Universidade Federal de Minas Gerais, Belo Horizonte, MG, Brazil.

Correspondence: Luciana Lemos de Azevedo; Rua Alagoas, 1314 / sala 1313; 30130-160 Belo Horizonte MG, Brasil; E-mail: azevedoll@gmail.com

Conflict of interest: There is no conflict of interest to declare.

Support: Study carried out at the Federal University of Minas Gerais (UFMG). Belo Horizonte, Brazil.

Received 02 June 2014; Received in final form 19 September 2014; Accepted 08 October 2014.
} 
The Lee Silverman Voice Treatment ${ }^{\circledR}\left(\right.$ LSVT $\left.^{\circledR}\right)$ - Lee Silverman Method of Voice Treatment - is a program of intensive speech treatment for PD patients, presenting as single focus the phonation at high intensity. This reflects indirectly in the improvement of other vocal parameters such as articulation, intonation and emission time ${ }^{12}$. Such speech rehabilitation is based on physiological therapy, focusing on glottal efficiency.

The present study aimed to study the effect of speech therapy and drug treatments on prosodic parameters employed in the expression of the attitudes expressed in the oral expression in patients with idiopathic PD (IPD).

\section{METHOD}

This study was approved by the Ethics Committee in Research of the Universidade Federal de Minas Gerais, according to the sentence no. 001/02. Thus, all subjects involved signed a consent form enabling their participation in the study.

\section{Individuals and corpus}

Ten patients with IPD, using levodopa, were selected, being five men ranging from 59 to 88 years of age (mean of 70.8 years) and five women, ranging from 59 to 75 years of age (mean 67.4 years).

All patients were submitted to clinical, audition, neurological and larynx evaluations. For neurological evaluation, the patients selected were the ones who had a diagnosis of IPD (according to the Brain Bank of the Parkinson's disease Society of the United Kingdom $)^{13}$ and who were among stages 2-3 on the Hoehn and Yahr scale ${ }^{14}$.

The patients selected by the above criteria underwent recording of the corpus in a sound-treated room. Individuals were asked to speak three sentences: "I closed the window" (Eu fechei a janela), "I won the pot" (Eu ganhei a panela), "I bought the cinnamon" (Eu comprei a canela). Such sentences were spoken in four stages: expressing attitudes of certainty $(\mathrm{AC})$ and doubt $(\mathrm{AD})$, and declarative $(\mathrm{DM})$ and interrogative modes (IM). To pronounce the sentences a context was added by using the induction method, so that the voice production should be as natural as possible. Parkinsonians were also asked to even speak the prolonged vowel [a].

The corpus was recorded on a Digital Audio Tape Recorder (DAT) Sony Brand, PCM-M1 model, through a headset microphone Leson HD-74, cardioid (unidirectional), laterally positioned two inches from the mouth of the parkinsonian patient.

The recording was made on two occasions: after abstention of the use of levodopa for a period of 12 hours (time off) and then one hour after administration of the drug (time on).

In the following week, parkinsonian patients begin the speech therapy (individually) using an adaptation of the
LSVT $^{\circledR}$ method. The LSVT ${ }^{\circledR}$ method is an intensive vocal treatment program (16 sessions of 50 minutes during a month, with four sessions per week) for patients with PD, presenting as the sole focus the phonation at high intensity. In the present study, we used an adaptation of this method, making 16 individual sessions of 50 minutes; however, with a frequency of twice a week (instead of four). Thus, the treatment shall last two months instead of one month.

\section{Parameters of the analysis}

The acoustic analysis were performed from the acoustic analysis WinPitch ${ }^{\circledR}$ programs, of Philippe Martin, version 1.8 and the VoxMetria ${ }^{\circledR}$, version 2.0, which allowed the analysis of the acoustic parameters of fundamental frequency $\left(\mathrm{F}_{0}\right)$, intensity and duration.

The $\mathrm{F}_{0}$ parameters analyzed were: highest $\mathrm{F}_{0}$ value of the prominent tonic (PT), lowest $\mathrm{F}_{0}$ value of $\mathrm{PT}$, amplitude of melodic variation of $\mathrm{PT}$, highest $\mathrm{F}_{0}$ value of unstressed pre-tonic (UPT) (which comes before the PT), lowest $\mathrm{F}_{0}$ value of UPT, amplitude of melodic variation of the UPT, the highest $F_{0}$ value of the utterance, the lowest value of $\mathrm{F}_{0}$ of the utterance, composition of the utterance, rate of change of melodic variation of the PT (composition divided by the duration of the PT), rate of change of melodic variation of UPT (composition divided by the duration of the UPT), initial $F_{0}$ of the utterance (taken in the middle of the vowel [i] the word "I"), $F_{0}$ value of the UPT (extracted in the middle of the vowel [a], the UPT), $\mathrm{F}_{0}$ value of the PT (extracted in the middle of the vowel [ $\varepsilon]$, the PT), final $\mathrm{F}_{0}$ value of the utterance (taken in the middle of the vowel [a] of the last word). Regarding the parameter of duration we analyzed: the duration of PT, the duration of the UPT, total duration of the utterance, starting point of the UPT and starting point of the PT. The analysis of the intensity involved the parameters: maximum intensity of the utterance, minimum intensity of utterance, intensity's variation during the emission (speech) of the sentences, average intensity of the utterance and average intensity of the prolonged vowel [a]. Measures of intensity and composition of the utterance $\left(\mathrm{F}_{0}\right.$ variability) were obtained through VoxMetria $^{\circledR}$ program and the other measures were extracted from the WinPitch ${ }^{\circledR}$ program.

The analysis of the variables extracted from the acoustic analysis was sub-divided into three comparison groups:

(i) 1) PD OFF x PD LSVTa OFF: to check whether, after speech therapy, any improvement occurred in the employment of prosodic parameters, even without the action of levodopa;

(ii) 2) PD OFF x PD LSVTa ON: in order to check whether, after administration of both treatments, there is improvement in the use of prosodic parameters;

(iii) 3) PD ON x PD LSVTa ON: to verify whether, in the situation in which the patient is usually on levodopa 
usage (on) and after speech therapy, it is possible to observe improvement in prosody.

The statistical analysis of the data was performed using the MINITAB program. From the mentioned software, the F test was performed in order to determine possible differences between the two comparative groups and between attitudes and modalities.

\section{RESULTS}

When comparing the groups PD OFF x PD LSVTa OFF, PD OFF $x$ PD LSVTa ON and PD ON x PD LSVTa ON, none statistically significant differences, in the prosodic parameters analyzed between the DM and AC and between the IM and $\mathrm{AD}$ were observed (as noted in the first column of Tables 1, 2 and 3). Thus, all sentences were analyzed together for all comparison groups, not taken into account the attitudes, as proposed in the objective of this study.

When we compared the groups, a methodology to verify the existence of any statistically significant difference between men and women for all variables was adopted as noted in the second column of the tables. If there were differences, the variable was analyzed separately by gender, and separated values were presented (as noted in the last column of the tables). For variables that showed no statistically significant difference between genders, the p-value resulting from the comparison between the groups considering individuals of both sexes was shown.

When comparing the groups PD OFF and PD LSVTa OFF, the variables that showed statistically significant differences between genders were: change rate of melodic variation of UPT ( $p=0.05)$, duration of the utterance $(p=0.03)$ and average of intensity of utterance $(p=0.00)$.

Regarding the variable rate of change of melodic variation of UPT, there was statistically significant difference only in women $(p=0.00)$, which was greater for PD LSVTa OFF. Regarding the duration of the sentence, there were statistically significant differences for women $(p=0.01)$ and men ( $p=0.00$ ), expressed by a reduction in the duration after speech therapy treatment. As for the variable average intensity of the utterance, we found statistically significant difference only in women $(p=0.00)$ with lower average intensity in the PD LSVTa OFF group.

Considering the analysis without gender distinction, we noted a statistically significant difference between PD OFF and PD LSVTa OFF regarding the amplitude of UPT'S melodic variation $(p=0.00)$, composition of the utterance $(p=0.05)$ and the rate of change of PT's melodic variation $(p=0.00)$, with increased values after speech therapy. The PT and the UPT's durations were reduced after the adapted $\operatorname{LSVT}^{\circledR}(p=0.00)$. Regarding the intensity average of the prolonged vowel [a] variable $(\mathrm{p}=0.01)$, an increase was also observed after speech therapy.

When PD OFF and PD LSVTa ON groups were compared, we found statistically significant difference between genders

Table 1. Significance values (p) when comparing the attitudes and modalities and women and men, and their average and respective standard deviation and significance value (p) in the comparison of data between PD OFF and PD LSVTa OFF groups.

\begin{tabular}{|c|c|c|c|c|c|}
\hline \multirow{3}{*}{ Variable } & \multicolumn{2}{|l|}{$p$-value } & \multicolumn{2}{|c|}{ Average and SD } & \multirow{3}{*}{$\mathrm{p}$-value } \\
\hline & \multirow{2}{*}{\multicolumn{2}{|c|}{ Attitudes $\times$ Modalities Women $\times$ Men }} & & & \\
\hline & & & PD OFF & PD LSVTa OFF & \\
\hline Amplitude of PT's melodic variation (Hz) & 0.73 & 0.37 & $23.98 \pm 22.68$ & $28.98 \pm 25.15$ & 0.06 \\
\hline Amplitude of UPT's melodic variation $(\mathrm{Hz})$ & 0.41 & 0.23 & $12.66 \pm 8.64$ & $16.74 \pm 10.56$ & $0.00 *$ \\
\hline Composition of utterance $(\mathrm{Hz})$ & 0.98 & 0.19 & $90.76 \pm 59.96$ & $102.75 \pm 58.93$ & $0.05^{\star}$ \\
\hline Displacement presence of the PT (\%) & 0.42 & 0.84 & $25.86 \pm 43.98$ & $30.17 \pm 46.10$ & 0.38 \\
\hline Rate of change of PT's melodic variation ( $\mathrm{Hz} / \mathrm{ms})$ & 0.72 & 0.58 & $0.13 \pm 0.12$ & $0.20 \pm 0.15$ & $0.00 *$ \\
\hline Rate of change of UPT's melodic variation $(\mathrm{Hz} / \mathrm{ms})$ & 0.65 & $0.05^{*}$ & & & \\
\hline Female & & & $0.12 \pm 0.08$ & $0.22 \pm 0.11$ & $0.00 *$ \\
\hline Male & & & $0.11 \pm 0.12$ & $0.14 \pm 0.11$ & 0.25 \\
\hline PT's duration (ms) & 0.90 & 0.98 & $190.50 \pm 77.55$ & $145.18 \pm 44.43$ & $0.00 *$ \\
\hline UPT's duration (ms) & 0.48 & 0.36 & $119.04 \pm 59.59$ & $87.72 \pm 19.46$ & $0.00 *$ \\
\hline Utterance duration (ms) & 0.62 & $0.03^{*}$ & & & \\
\hline Female & & & $1327.40 \pm 401.20$ & $1100.40 \pm 191.60$ & $0.01 *$ \\
\hline Male & & & $1561.90 \pm 634.90$ & $1117.30 \pm 205.20$ & $0.00 *$ \\
\hline Intensity variation during the utterance $(\mathrm{dB})$ & 0.87 & 0.12 & $40.42 \pm 5.20$ & $39.77 \pm 6.80$ & 0.40 \\
\hline Utterance intensity average (dB) & 0.77 & $0.00 *$ & & & \\
\hline Female & & & $82.87 \pm 7.75$ & $75.54 \pm 7.78$ & $0.00 *$ \\
\hline Male & & & $86.19 \pm 5.14$ & $87.60 \pm 7.63$ & 0.70 \\
\hline Prolonged vowel intensity average $[\mathrm{a}](\mathrm{dB})$ & - & 0.59 & $81.95 \pm 8.86$ & $89.34 \pm 5.53$ & $0.01 *$ \\
\hline
\end{tabular}

LSVTa: Lee Silverman Voice Treatment adapted; OFF: Without the effect of levodopa; PT: Prominent tonic; PD: Parkinson's disease; UPT: Unstressed pretonic; SD: Standard deviation. 
Table 2. Significance values $(p)$ when comparing the attitudes and modalities and women and men, and their average and respective standard deviation and significance value $(p)$ in the comparison of data between PD OFF and PD LSVTa ON groups.

\begin{tabular}{|c|c|c|c|c|c|}
\hline \multirow{2}{*}{ Variable } & \multicolumn{2}{|l|}{$p$-value } & \multicolumn{2}{|c|}{ Average and SD } & \multirow{2}{*}{$\mathrm{p}$-value } \\
\hline & Attitudes $\times$ Modalities & Women $x$ Men & PD OFF & PD LSVTa ON & \\
\hline Amplitude of PT’s melodic variation $(\mathrm{Hz})$ & 0.88 & 0.78 & $23.98 \pm 22.68$ & $29.05 \pm 25.24$ & 0.06 \\
\hline Amplitude of UPT's melodic variation $(\mathrm{Hz})$ & 0.74 & 0.70 & $12.66 \pm 8.64$ & $14.24 \pm 10.72$ & 0.17 \\
\hline Composition of utterance $(\mathrm{Hz})$ & 0.93 & 0.33 & $90.76 \pm 59.96$ & $100.09 \pm 61.12$ & 0.10 \\
\hline Displacement presence of the PT (\%) & 0.90 & 0.65 & $25.86 \pm 43.98$ & $25.00 \pm 43.48$ & 0.91 \\
\hline Rate of change of PT's melodic variation ( $\mathrm{Hz} / \mathrm{ms})$ & 0.84 & 0.80 & $0.13 \pm 0.12$ & $0.19 \pm 0.16$ & $0.00 *$ \\
\hline Rate of change of UPT's melodic variation $(\mathrm{Hz} / \mathrm{ms})$ & 0.60 & 0.61 & $0.12 \pm 0.10$ & $0.16 \pm 0.12$ & $0.00 *$ \\
\hline PT's duration & 0.95 & 0.96 & $190.50 \pm 77.55$ & $150.09 \pm 45.89$ & $0.00 *$ \\
\hline UPT's duration (ms) & 0.70 & 0.57 & $119.04 \pm 59.59$ & $90.19 \pm 21.65$ & $0.00 *$ \\
\hline Utterance duration (ms) & 0.49 & $0.05^{\star}$ & & & \\
\hline Female & & & $1327.40 \pm 401.20$ & $1076.50 \pm 205.20$ & $0.00 *$ \\
\hline Male & & & $1561.90 \pm 634.90$ & $1108.40 \pm 205.60$ & $0.00 *$ \\
\hline Intensity variation during the utterance $(\mathrm{dB})$ & 0.77 & 0.14 & $40.42 \pm 5.20$ & $41.41 \pm 6.15$ & 0.18 \\
\hline Utterance intensity average $(\mathrm{dB})$ & 0.54 & $0.00 *$ & & & \\
\hline Female & & & $82.87 \pm 7.75$ & $76.17 \pm 6.33$ & $0.00 *$ \\
\hline Male & & & $86.19 \pm 5.14$ & $86.32 \pm 6.39$ & 0.99 \\
\hline Prolonged Vowel intensity average [a] (dB) & - & 0.72 & $81.95 \pm 8.86$ & $88.09 \pm 6.05$ & $0.03 *$ \\
\hline
\end{tabular}

LSVTa: Lee Silverman Voice Treatment adapted; OFF: Without the effect of levodopa; ON: Under the effect of levodopa; PT: Prominent tonic; PD: Parkinson's disease; UPT: Unstressed pre-tonic; SD: Standard deviation.

for the variables utterance duration and the utterance intensity average. Regarding the utterance duration variable, we noticed a statistically significant difference for both genders $(\mathrm{p}=0.00)$, expressed by reduced duration in the PD LSVTa ON group. As for the utterance intensity average variable, a statistically significant difference was observed only in women $(p=0.00)$, with lower intensity average for PD LSVTa ON.
Performing the analysis without distinction of gender, there was a statistically significant difference $(p=0.00)$ regarding the rate of change of PT and UPT's melodic variations, both increasing after the combination of speech therapy and drug treatment. Moreover, PT and UPT's durations were significantly reduced $(p=0.00)$ after association of the treatments. The intensity average of the prolonged

Table 3. Significance values $(p)$ when comparing the attitudes and modalities and women and men, and their average and respective standard deviation and significance value (p) in the comparison of data between PD ON and PD LSVTa ON groups.

\begin{tabular}{|c|c|c|c|c|c|}
\hline \multirow{2}{*}{ Variable } & \multicolumn{2}{|l|}{$p$-value } & \multicolumn{2}{|c|}{ Average and SD } & \multirow{2}{*}{$\mathrm{p}$-value } \\
\hline & \multicolumn{2}{|c|}{ Attitudes $\times$ Modalities Women $\times$ Men } & PD ON & PD LSVTa ON & \\
\hline Amplitude of PT's melodic variation $(\mathrm{Hz})$ & 0.87 & 0.48 & $22.20 \pm 9.61$ & $29.05 \pm 25.24$ & $0.01 *$ \\
\hline Amplitude of UPT's melodic variation $(\mathrm{Hz})$ & 0.48 & 0.16 & $11.63 \pm 7.86$ & $14.24 \pm 10.72$ & $0.03 *$ \\
\hline Composition of utterance $(\mathrm{Hz})$ & 0.87 & 0.17 & $81.88 \pm 8.50$ & $100.09 \pm 61.12$ & $0.00 *$ \\
\hline Displacement presence of the PT (\%) & 0.76 & 0.33 & $0.24 \pm 0.43$ & $0.25 \pm 0.43$ & 0.86 \\
\hline Rate of change of PT's melodic variation ( $\mathrm{Hz} / \mathrm{ms})$ & 0.86 & 0.25 & $0.14 \pm 0.10$ & $0.19 \pm 0.16$ & $0.00 *$ \\
\hline Rate of change of UPT's melodic variation $(\mathrm{Hz} / \mathrm{ms})$ & 0.69 & $0.03^{*}$ & & & \\
\hline Female & & & $0.11 \pm 0.07$ & $0.18 \pm 0.14$ & $0.01 *$ \\
\hline Male & & & $0.15 \pm 0.12$ & $0.15 \pm 0.11$ & 0.99 \\
\hline PT's duration (ms) & 0.99 & 0.06 & $150.40 \pm 44.00$ & $150.09 \pm 45.89$ & 0.96 \\
\hline UPT's duration (ms) & 0.90 & $0.00 *$ & & & \\
\hline Female & & & $96.82 \pm 18.92$ & $84.98 \pm 19.02$ & $0.01 *$ \\
\hline Male & & & $91.38 \pm 19.27$ & $95.69 \pm 23.02$ & 0.67 \\
\hline Utterance duration (ms) & 0.73 & 0.76 & $1125.00 \pm 222.20$ & $1092.50 \pm 205.20$ & 0.24 \\
\hline Intensity variation during the utterance $(\mathrm{dB})$ & 0.97 & 0.73 & $39.42 \pm 5.01$ & $41.41 \pm 6.16$ & $0.01 *$ \\
\hline Utterance intensity average (dB) & 0.97 & $0.05^{\star}$ & & & \\
\hline Female & & & $82.15 \pm 7.38$ & $76.18 \pm 6.33$ & $0.00 *$ \\
\hline Male & & & $89.12 \pm 7.91$ & $86.33 \pm 6.39$ & 0.08 \\
\hline Prolonged Vowel intensity average [a] (dB) & - & 0.33 & $84.31 \pm 8.21$ & $88.09 \pm 6.05$ & 0.14 \\
\hline
\end{tabular}

LSVTa: Lee Silverman Voice Treatment adapted; ON: Under the effect of levodopa; PT: Prominent tonic; PD: Parkinson's disease; UPT: Unstressed pre-tonic; SD: Standard deviation. 
vowel [a] variable significantly increased $(p=0.03)$ after the treatments.

Comparing the PD ON and PD LSVTa ON groups, we observed statistically significant differences between the genders for the variables: change of UPT's melodic variation, UPT's duration and utterance intensity average. These variables were statistically significant only in women. The change of UPT's melodic variation $(\mathrm{p}=0.01)$ was higher in PD LSVTa ON group, while the duration of UPT ( $p=0.01$ ) and the intensity average of the utterance $(p=0.00)$ were lower in PD LSVTa ON group.

Performing an analysis without distinction of gender, there were statistically significant differences in the amplitude of PT ( $=0.01)$ and UPT's $(p=0.03)$ melodic variations, for the composition of the utterance $(p=0.00)$, rate change of PT's melodic variation $(p=0.00)$, intensity variation during the utterance $(p=0.01)$, with all higher measures in the PD LSVTa ON group.

\section{DISCUSSION}

When comparing the PD OFF and PD LSVTa OFF groups, we observed statistically significant differences for variables involving the parameters of frequency, intensity and duration.

For $\mathrm{F}_{0}$ variables, it was observed that after speech therapy patients with PD presented higher measures. The improvement in the $\mathrm{F}_{0}$ parameters after treatment with the adapted LSVT ${ }^{\circledR}$ method is in accordance to several studies reporting the effectiveness of LSVT ${ }^{\mathbb{R}}$ method in improving the intonation ${ }^{15,16,17,18}$.

Regarding the variables of duration, there was a reduction after speech therapy. This improvement of the prosodic parameter of duration - even the focus of the LSVT ${ }^{\circledR}$ being the prosodic parameter intensity - is due to the fact that the LSVT $^{\mathbb{R}}$ presents as its central focus the phonation at high intensity, which provides a single organized motor schema that facilitates the generalization on other systems, i.e., reflecting on the improvement of other vocal parameters ${ }^{12,14,15,16,17,18}$.

About the intensity average of the prolonged vowel [a] variable, an increase was also observed after speech therapy. This finding is in agreement with the reports found in the literature, that the LSVT $^{\mathbb{R}}$ has as one of its benefits, an increase in vocal intensity ${ }^{16,17,18,19,20}$. Importantly, in women we observed a lower intensity average for the PD LSVTa OFF group, which contradicts the studies cited.

Comparing the PD OFF and PD LSVTa ON groups, there were statistically significant differences between the groups with regard to variables involving the parameters of frequency, intensity and duration.

Some studies ${ }^{2,11}$ found that levodopa might reduce the duration parameter; possibly because it improves bradykinesia symptoms, leaving the duration of the production of the segments lower after the administration of the drug. During a study ${ }^{21}$ it was found that prolonged use of levodopa can diminish the performance in patients with PD.

The improvement of the three prosodic parameters associating both treatments (medication and speech therapy) was expected since the levodopa presents this effect in the parameter of duration and the adapted LSVT $^{\circledR}$ method shows the same effect for the parameters $\mathrm{F}_{0}$ and intensity.

When comparing the PD ON and PD LSVTa ON groups, with regard to the $\mathrm{F}_{0}$ parameter, we observed a more significant increase of the measures after treatments association. These findings highlight the importance of the association of speech therapy to medication in the improvement of the communicative performance of parkinsonian patients, given that the measures of $F_{0}$ were not affected by levodopa, but by LSVTa ${ }^{2,11,15,16,17}$.

About the variables of duration there were no differences between the groups compared. This finding is in agreement with those already reported in the present study ${ }^{2,11}$, showing that the speech therapy is not as effective in improving the duration parameter as the drug therapy. However, the addition of speech therapy to drug treatment did not significantly affect these variables, except for the variable UPT's duration in women.

Regarding the intensity parameter, the variation of intensity during the utterance increased after treatments association, which ultimately reflects an improvement in the vocal expression of the parkinsonian patient, given that a greater variation in intensity during the utterance (associated with composition increase) causes an improvement in the characteristic of monotonous speech of these individuals. Importantly, the variable average of intensity of the utterance was lower in PD LSVTa ON for women. One study ${ }^{22}$ examined the effect of levodopa on breathing and phonation of individuals with IPD and no significant increase in vocal intensity as a function of levodopa was observed. The use of wind instrument, according to a study $^{23}$, can optimize the glottal adduction and improve respiratory control. In contrast, another study ${ }^{24}$ found that voice intensity of IPD patients tends to increase after drug administration.

A recent study ${ }^{25}$ reported that the Parkinson disease does not make the patient use prosody to express his/her attitudes differently from the control group, however, when the attitudes were not taken into account, it was observed that levodopa was effective in the improvement of the parameter of duration. This finding reinforces the importance of the association of speech therapy to medication aiming to improve the communicative performance of parkinsonian patients.

In conclusion, when comparing the groups with PD OFF $x$ PD LSVTa OFF and PD OFF $x$ PD LSVTa ON we found that the speech therapy through the adapted LSVT ${ }^{\mathbb{R}}$ method, as well as the association of speech therapy and drug treatments, 
causes an improvement of the vocal expression of parkinsonian patients, once we observed an increase of $F_{0}$ measures, reduction of measures of duration and higher average of vocal intensity in the production of the prolonged vowel [a]. Regarding the comparison between the groups with PD ON $x$ PD LSVTa ON we also observed an improvement in the vocal expression of parkinsonian patients determined, mainly, by increased of the $\mathrm{F}_{0}$ measures. However, we also observed a reduction in the UPT's duration in women and greater variation in vocal intensity during the production of utterances.

Given that levodopa is effective in improving the duration parameter, the association of speech therapy is of great value to improve other prosodic parameters $\left(\mathrm{F}_{0}\right.$ and intensity) in order to enable more efficient communication performance for the parkinsonian patient, thus improving his/ her quality of life.

\section{References}

1. Silveira DN, Brasolotto AG. Reabilitação vocal em pacientes com doença de Parkinson: fatores interferentes. Pró-Fono Rev Atual Cientific. 2005;17(2):241-50. http://dx.doi.org/10.1590/S010456872005000200013

2. Azevedo LL, Cardoso F, Reis C. Análise acústica da prosódia em mulheres com doença de Parkinson: efeito da Levodopa. Arq Neuropsiquiatr. 2003;61(4):995-8. http://dx.doi.org/10.1590/S0004282X2003000600020

3. Coutinho SB, Diaféria G, Oliveira G, Behlau M. Voz e fala de Parkinsonianos durante situações de amplificação, atraso e mascaramento. Pró-Fono Rev Atual Cientific. 2009;21:219-24.

4. Soares MFP, Albano EC. Dinâmica da produção da fala em sujeitos portadores de doença de Parkinson: análise das vogais. In: Caderno de Resumos do IX Congresso Nacional e III Congresso Internacional de Fonética e Fonologia; 27 a 29 nov 2006; Belo Horizonte, Brasil. Belo Horizonte: UFMG; 2006. vol 1, p. 13.

5. Lima SSP, Quagliato EMAB, Cagliari LC, Souza EAP. Linguagem e isolamento social no mal de Parkinson. Rev Soc Bras Fonoaudiol. 1997;1(1):5-13.

6. Sanabria J, Ruiz PG, Gutierrez R, Marquez F, Escobar P, Gentil M, Cenjor C. The effect of levodopa on vocal function in Parkinson's disease. Clin Neuropharmacol. 2001;24(2):99-102. http://dx.doi.org/ 10.1097/00002826-200103000-00006

7. Jorge TM, Lamônica DAC, Caldana ML. Doença de Parkinson: transtornos da comunicação oral e gráfica. Fono Atual. 2004;7(30):14-25.

8. Pawlas AA, Ramig LO, Countryman S. Perceptual voice and speech characteristics in patients with idiopathic Parkinson. NCVS Status and Progress Report. 1996;10:79-87.

9. Illes J. Language production in Parkinson's disease: acoustic and linguistic considerations. Brain Lang. 1988;33(1):146-60. http://dx. doi.org/10.1016/0093-934X(88)90059-4

10. Hely MA, Fung VS, Morris JG. Treatment of Parkinson's disease. J. Clin. Neurosci. 2000;7(6):484-94. http://dx.doi.org/10.1054/jocn.2000.0766

11. Azevedo LL, Cardoso F, Reis C. Análise acústica da prosódia em mulheres com doença de Parkinson: comparação com controles normais. Arq Neuropsiquiatr. 2003;61(4):999-1003.

12. Fox CM, Ramig LO, Ciucci MR, Sapir S, McFarland DH, Farley BG. The science and practice of LSVT/LOUD: neural plasticity-principled approach to treating individuals with Parkinson disease and other neurological disorders. Semin Speech Lang. 2006;27(4):283-99. http://dx.doi.org/10.1055/s-2006-955118

13. Hughes AJ, Daniel SE, Kilford L, Lees AJ. Accuracy of clinical diagnosis of idiopathic Parkinson's disease: a clinico-pathological study of 100 cases. J Neurol Neurosurg Psychiatry. 1992;55(3):181-4. http://dx.doi.org/10.1136/jnnp.55.3.181
14. Hoehn MM, Yahr MD. Parkinsonism: onset, progression and mortality. Neurology. 1967;17(5):427-42. http://dx.doi.org/10.1212/ WNL.17.5.427

15. Dromey C, Ramig LO, Johnson AB. Phonatory and articulatory changes associated with increased vocal intensity in Parkinson disease: a case study. J Speech Hear Res. 1995;38(4):751-64. http:// dx.doi.org/10.1044/jshr.3804.751

16. Smith ME, Ramig LO, Dromey C, Perez KS, Samandari R. Intensive voice treatment in Parkinson disease: laryngoestroboscopic findings. J Voice. 1995;9(4):453-9. http://dx.doi.org/10.1016/S0892-1997(05) 80210-3

17. Ramig LO, Countryman S, O’Brien C, Hoehn M, Thompson L. Intensive speech treatment for patients with Parkinson's disease: short and long term comparison of two techniques. Neurol. 1996;47(6):1496-504. http://dx.doi.org/10.1212/WNL.47.6.1496

18. Ferreira FV, Cielo CA, Trevisan ME. Medidas vocais acústicas na doença de parkinson: estudo de casos. Rev CEFAC. 2010;12(5):889-98. http://dx.doi.org/10.1590/S1516-18462010005000020

19. Dromey C, Ramig LO, Johnson AB. Phonatory and articulatory changes associated with increased vocal intensity in Parkinson disease: a case study. J Speech Hear Res. 1995;38(4):751-64. http:// dx.doi.org/10.1044/jshr.3804.751

20. El Sharkawi A, Ramig L, Logemann JA, Paulosky BR, Rademaker AW, Smith $\mathrm{CH}$, et al. Swallowing and voice effects of Lee Silverman Voice Treatment (LSVT): a pilot study. J Neurol Neurosurg Psychiatry. 2002;72(1):31-6. http://dx.doi.org/10.1136/jnnp.72.1.31

21. Mourão LF, Aguiar PMC, Ferraz FAP, Behlau MS, Ferraz HB. Acoustic voice assessment in parkinson's disease patients submitted to posteroventral pallidotomy. Arq Neuropsiquiatr. 2005;63(1):20-5. http://dx.doi.org/10.1590/S0004-282X2005000100004

22. Guedes LU, Azevedo LL, Cardoso F, Parreira VF, Reis C. Efeito da levodopa sobre a respiração e fonação dos indivíduos com doença de Parkinson idiopática. In: Rev Soc Bras Fonoaudiol. 2005;Supl Esp. [Apresentado no 13o Congresso Brasileiro de Fonoaudiologia; 2005; Santos, BR].

23. Rosa JC, Cielo CA, Cechella C. Função fonatória em pacientes com doença de Parkinson: uso de instrumento de sopro. Rev CEFAC. 2009;11(2):305-13. http://dx.doi.org/10.1590/S1516-18462009000200016

24. Jiang J, Lin E, Wang J, Hanson DG. Glottographic measures before and after levodopa treatment in Parkinson's disease. Laryngoscope. 1999;109(8):1287-294. http://dx.doi.org/10.1097/00005537-19990800000019

25. Azevedo LL, Reis CAC, Souza IS, Cardoso FEC. Prosody and levodopa in Parkinson's disease. Arq Neuropsiquiatr. 2013;71(11):835-40. http://dx.doi.org/10.1590/0004-282X20130141 